\title{
Pencurian e-money pada e-commerce dalam Tindak Pidana Cybercrime sebagai Tindak Pidana Ekonomi
}

\author{
Muhammad Ramadhan ${ }^{1}$, Dwi Oktafia Ariyanti ${ }^{2}$ dan Nita Ariyani ${ }^{3}$ \\ ${ }^{1,2,3}$ Fakultas Hukum, Universitas Janabadra \\ Corresponding author. Email: muhammad_ramadhan@ janabadra.ac.id
}

Naskah diterima: 07-08-2020; revisi: 07-12-2020; disetujui: 16-12-2020

DOI: https://doi.org/10.46257/jrh.v24i2.179

\begin{abstract}
Abstrak
Kemajuan teknologi merupakan suatu perkembengan jaman yang membawa peradaban manusia menjadi semakin modern. Perkembangan yang membuat kinerja manusia semakin lebih baik dan mudah dengan adanya teknologi digital, baik pada aspek pendidikan, pekerjaan, pemerintahan dan khususnya pada bidang ekonomi. Dengan adanya teknologi digital pertumbuhan perekonomian suatu bangsa dapat melaju dengan pesat oleh karena itu teknologi memeiliki peranan penting dalam membangun suatu bangsa, akan tetapi dengan majunya teknologi juga turut diisi dengan kejahatan jenis baru dibidang digital, khususnya cybercrime sebagai kejahatan ekonomi. Oleh karena itu dalam penulisan ini diambil rumusan masalah bagaimana pandangan hukum pidana dalam tindak pidana pembobolan rekening dan uang elektronik pada e-commerce sebagai kejahatan ekonomi, adapun tujuan mengetahui konsep hukum pidana dalam memandang kejahatan cybercrime sebagai kejahatan ekonomi, kegunaan dari hasil penelitian ini adalah sebagai bentuk pembaharuan hukum pidana dengan adanya kejahatan jenis baru sebagai dampak dari perkembangan jaman. Metode yang digunakan dalam penelitian ini adalah yuridis normatif, hasil penelitian bahwa cybercrime yang dapat dikatakan sebagai kajahatan ekonomi adalah kejahatan yang dilakukan dengan motif utamanya adalah mengenai harta benda, sehingga bila kejahatan tersebut dibiarkan akan memberikan dampak pada perekonomian bangsa dengan ditandainya berkurangnya minat masyarakat untuk melakukan transaksi secara online dan menabung uang direkening bank, yang nantinya akan berpengaruh terhadap menurunnya perekonomian negara, kesimpulannya ialah kejahatan yang dilakukan oleh masyarakat tersebut dalam tindak pidana ekonomi salah satunya yang diangkat oleh penulis adalah mengenai pembobolan bank dalam hal ini rekening bank baik yang terjadi didalam e-commerce, dimana e-commerce itu sendiri merupakan transaksi yang dilakukan melalui teknologi tinggi antara indvidu yang satu dengan individu yang lain yang tidak ada batasnya atau jaraknya berjauhan.
\end{abstract}

Kata kunci: cyber crime, e-money, tindak pidana ekonomi.

\section{E-money Theft on e-commerce in Cybercrime as an Economic Crime}

\author{
Abstract \\ Advances in technology is a development that brings human civilization to \\ become more modern. Developments that make human performance even better
}


and easier with the presence of digital technology, both in the aspects of education, employment, government and especially in the economic field. With digital technology, the economic growth of a nation can progress rapidly, therefore technology plays an important role in building a nation, but with the advancement of technology is also filled with new types of crime in the digital field, especially cybercrime as economic crime. Therefore, in this paper the problem formulation is taken How is the view of criminal law in criminal acts of breaking into accounts and electronic money in e-commerce as an economic crime, while the purpose and usefulness of the results of this study is to find out the concept of criminal law in viewing cybercrime crimes as economic crimes and as a form of renewal of criminal law in the presence of new types of crime as a result of changing times. The method used in this study is normative juridical, by providing conclusions on the results of research that cybercrime which can be said to be economic kajahatan is a crime committed with the main motive is about property, so that if the crime is allowed it will have an impact on the nation's economy with a marked reduction people's interest in conducting transactions online and saving money in bank accounts, which in turn will affect the country's economic decline.

Keywords: Cyber crime, e-money, economic crimes.

\section{Pendahuluan}

Seiring berkembangnya peradaban manusia maka seiring pula tingkat kemajuan suatu bangsa, kemajuan suatu bangsa dapat di tandainya dengan berkembangnya suatu kecerdasan dangan timbulnya berbagai macam ilmu pengetahuan diantaranya adalah dengan kemajuan teknologi atau Ilmu Pengetahuan dan Teknologi (IPTEK).

Pada saat ini hampir semua bidang kehidupan memanfaatkan penggunaan TIK dalam menjalankan aktifitasnya. Mulai dari bidang ekonomi, pendidikan, kesehatan, pemerintahan, perbankan, agama dan juga sistem pertahanan dan keamanan suatu Negara. Berbagai manfaat dapat kita ambil dari penggunaan TIK ini sebagai contoh misalnya dalam bidang perbankan, dengan memanfaatkan TIK ini kita dapat menggunakan sms banking dan internet banking. Namun, disisi lain penggunaan teknologi berbasis internet seringkali disalah gunakan oleh pihak pihak yang tidak bertanggung jawab, sehingga seiring perkembangan jaman dengan kemajuan teknologi yang disalah gunakan maka akan berkembang pula suatu bentuk kriminalitas bahwa dengan suatu bentuk penyalahgunaan teknologi, penyalahgunaan teknologi tersebut menjadikan suatu bentuk tindak pidana dibidang telematika. 
Tindak pidana didunia maya sering kita kenal dengan istilah "cybercrime" atau "kejahatan siber". Istilah "cyber crime" itu sendiri saat ini sama dengan istilah "computer crime" (Al Wisnubroto, 2010: 1) Tindak pidana atau kejahatan siber ini dapat dilakukan oleh siapapun tanpa mengenal usia, waktu, batas, keadaan, cuaca dan lain sebagainya. Dahulu undang-undang hukum pidana dibuat untuk melindungi warga negara dan pribadi berupa : tubuh, nyawa, raga, benda atau harta kekayaan ataupun dengan kata lain segala sesuatu yang dapat dirasa, dicium, diihat atau diraba. Pada saat pembentukan dan diundangkan kitab undang-undang hukum pidana tidak terfikirkan bahwa nantinya akan muncul teknologi baru yang membuat dan memuat berbagai macam data data atau yang biasa disebut dengan teknologi komputer, sehingga KUHP sulit untuk menanggulangi atas kejahatan siber, dikarenakan unsur unsur yang harus terpenuhi dalam KUHP tidak dapat terpenuhi karena tindak kejahatan tersebut dilakukan didalam dunia maya. Kejahatan didalam lapisan masyarakat dapat ditinjau dari sudut pandang tertentu yang merupakan sebagai proses sosial, sehingga dalam penyelenggaraan penegakan hukum juga harus dilihat dari sudut politik kriminal dalam bentuk preventif (pencegahan) serta dalam penegakannya dalam bentuk represif dengan penegakan hukum pidana demikian pula terhadap kejahatan siber. Cyber crime bukanlah perbuatan tindak kriminal biasa, karena pelaku tindak pidana tersebut memiliki kecerdasan yang sangat berbeda dengan kejahatan konvensional dimana antara penegak hukum dengan pelaku memiliki intensitas kecerdasaan yang lebih maju dalam menguasai teknologi, sehingga sering kali aparat penegak hukum kesulitan dalam melakukan penegakan di bidang tindak pidana cyber crime terlebih lagi masyarakat Indonesia harus dilindungi baik secara fisik maupun harta benda. Perbuatan pidana yang dilakukan oleh masyarakat maya selain menjatuhkan harkat martabat seseorang, adalah dari segi motif ekonomi yang artinya berkaitan dengan materi walau tidak menutup kemungkinan perbuatan tersebut sama sekali tidak berkaitan dengan materi, yang artinya perbutan pidana tersebut memang di lakukan dengan tujuan-tujuan tertentu. Didalam perbuatan pidana pada prinsipnya adanya pelaku dan korban hanya saja di dalam dunia cyber crime antara pelaku 
dengan korban sama sama berada di dalam dunia maya walaupun tujuan akhir dari cyber crime dengan motif ekonomi adalah bentuk nyata yang digunakan sebagai bentuk keuntungan bagi pelaku. Memang jika di tinjau dari lahirnya perkembangan teknologi dengan adanya dunia maya akan berdampak dengan terhadap dunia bisnis atau perdagangan yang sangat besar, sebab segala macam bentuk perdagangan dapat di lakukan tanpa harus saling bertatap muka, dan dapat di lakukan secara jarak jauh. Bentuk perdagangan seperti ini akan sangat mempengaruhi perkembangan ekonomi, transaksi seperti ini atau biasa disebut dengan electrnic commerce (e-commerce) (Didik M. Arief dan Elisatris Gultom, 2005: 143).

Pada dasarnya teknologi sebetulnya merupakan sesuatu yang bersifat netral yang artinya bebas dari suatu nilai sehingga tidak di lekatkan sebuah sifat baik atau buruk, akan tetapi sampai pada perkembangannya banyak pihak pihak yang tergoda untuk melakukan tindak kejahatan yang artinya adalah penyalahgunaan suatu teknologi (Abdul Wahid dan Muhammad Labib, 2005: 59). Oleh karena itu teknologi dapat dikatakan pisau bermata dua yang satu sisinya sarana bagi para pelaku kejahatan untuk mendapatkan keuntungan dengan cara yang bertentangan dengan peraturan perundang-undangan yang nantinya dapat memberikan dampak yang berbahaya bagi stabilitas perekonomian. Adapun rumusan masalah yang dikaji dalam penellitian ini addalah Bagaimana pandangan hukum pidana dalam tindak pidana pembobolan rekening dan uang elektronik pada e-commerce sebagai kejahatan ekonomi?

Metode penelitian dalam penulisan hukum ini, jenis penelitian yang digunakan adalah penelitian normatif yakni Kerangka peraturan perundang undangan, pembuktian melalui pasal, teori-teori sosiologi hukum, pembuktian melalui masyarakat. Penggunaan jenis penelitian normatif dalam penelitian ini dapat dilihat dari aspek normatif yakni mencoba menganalisis permasalahan yang ada pada norma dan teori tersebut. Penelitian yang menggunakan bahan kepustakaan sebagai bahan yang utama, dengan berdasarkan tataran asas teori yang terkandung didalam peraturan perundang - undangan yang dibenturkan 
dengan permasalahan dan kemudian dianalisa berdasarkan asas - asas serta teori - teori hukum yang ada sebagai pisau analisa.

Metode pendekatan yang digunakan dalam penelitian ini adalah:

a. Pendekatan perundang-undangan (statute-approach). Penelitian dilakukan terhadap produk-produk hukum yang hendak diteliti. Mengenai tindak pidana cyber crime terhadap peraturan yang terkait atas tindak pidana cyber crime.

b. Pendekatan Analitis (Analytical Approach). Menganalisis terhadap bahan hukum untuk mengetahui makna yang dikandung oleh istilah-istilah yang digunakan dalam aturan perundang-undangan secara konsepsional, sekaligus mengetahui penerapannya dalam praktik maupun dalam putusanputusan hukum yang berkaitan dengan permasalahan tindak pidana pembobolan rekening bank atau pun e-money dalam e-commerce.

c. Pendekatan kasus (Case approach). Untuk mempelajari penerapan normanorma atau kaidah-kaidah hukum yang dilakukan dalam praktik hukum.

Data yang diperoleh dianalisa dengan menggunakan metode kualitatif dengan menjabarkan dan memberikan interpretasi terhadap data yang diperoleh berdasarkan norma-norma hukum, teori-teori dan doktrin yang berlaku dihubungkan dengan pokok permasalahan.(Soerjono Soekanto, 1988: 12) Bahan hukum yang diperoleh dalam penelitian studi kepustakaan, aturan perundangundangan terutama yang mengatur menganai penegakan hukum pidana terhadap pembobolan rekening bank dan e-money pada transaksi e-commerce dan bahan hukum penunjang lainnya, penulis menguraikan dan menghubungkan sedemikian rupa, sehingga disajikan dalam penulisan yang lebih sistematis guna menjawab permasalahan yang telah dirumuskan.

Bahwa cara pengolahan bahan hukum dilakukan secara deduktif yakni menarik kesimpulan dari suatu permasalahan yang bersifat umum terhadap permasalahan yang konkret yang dihadapi, terutama kejahatan yang berkaitan dengan dunia maya sebagai bentuk perkembangan zaman. 


\section{Pembahasan}

\section{A. Perbedaan Cyber Crime dengan Tindak Pidana Konvensional}

Tindak pidana cyber crime merupakan suatu tindak pidana yang memang memerlukan perhatian khusus. Cybercrime menjadi isu yang menarik dan kadang menyulitkan karena Kegiatan dunia cyber tidak dibatasi oleh teritorial negara apabila pelaku melakukan dari negara yang berbeda. Kegiatan dunia cyber relatif tidak berwujud karena tindak pidana tersebut dilakukan di dalam cyber space atau dunia maya, sulitnya pembuktian karena data elektronik relatif mudah untuk diubah dan lebih mudah untuk menghilangkan jejak.

Perbuatan pidana akan ikut berkembang menyesuaikan dengan kemajuan teknologi yang ada di masyarakat. Bahkan sangat tidak memungkinkan bahwa kejahatan akan jauh lebih berkembang dari pada suatu ilmu pegetahuan. Oleh karena itu diperlukannya suatu modernisasi dari hukum pidana agar dapat menyesuaikan dari yang namanya suatu modernisassi perkembangan zaman.

Di dalam Hukum pidana terdapat 3 (Tiga) segi yang terpengaruh dari suatu modernisasi, yakni (Sudarto, 1983: 31):

1. Hukum Pidana yang kita cita citakan atau hukum pidana ius constituendum;

2. Hukum Pidana yang berlaku sekarang, artinya yang harus diterapkan oleh pengadilan, atau disebut hukum pidana sebagai ius constitutum atau ius operandum; dan

3. Hukum pidana yang benar benar diterapkan untuk suatu perbuatan konkrit, atau hukum pidana sebagai ius operatum.

Dari ketiga segi tersebut dapat dikatakan bahwa adanya suatu bentuk pembaharuan dalam segi hukum pidana, yang artinya hukum pidana yang berlaku di indonesia kurang memadai dalam hal penegakan dan penanggulangan atas perbuatan cyber crime (penal reform), hal tersebut disebabkan karena ketentuan yang di atur di dalam KUHP tidak adanya unsur mengenai atau menggunakan sebuah sarana elektronik, dalam hal ini terdapat pembaharuan hukum pidana. Dalam hukum pidana itu sendiri terdapat 3 (Tiga) pokok permasalahan, yakni (Sudarto, 1983: 31):

1. Perbuatan yang dilarang 


\section{Orang yang melakukan perbuatan dilarang itu}

3. Pidana yang diancamkan terhadap pelanggaran larangan itu.

Dari situ dapat dilihat bahwa adanya suatu perbuatan yang dilarang dalam undang udang sehingga dapat dikatakan bahwa perbuatan tersebut merupakan perbuatan pidana. Dalam hal ini perbuatan atau interaksi dalam dunia maya harus yang sekiranya dan sifatnya merugikan orang lain harus di atur terlebih dahulu sebagai bentuk perbuatan yang melawan hukum atau perbuatan yang dilarang. Sebab perbuatan yang dilakukan di dalam dunia maya sifatnya berbeda dengan dunia nyata, walaupaun memiliki kesamaan antara keduanya dimana cyber crime merupakan tindak pidana konvensional pada umumnya hanya saja lebih menggunakan teknologi sebagai bantuannya.

Perbuatan pidana yang terjadi di dunia maya terkadang juga merupakan suatu bentuk refleksi atas apa yang terjadi di dalam dunia nyata, seperti halnya pencemaran nama baik atau pelecehan sex (cyber sex) dimana motif yang dilakukan atas dasar bahwa adanya rasa takut bila menghadapi lawan atau saingan mereka, dimana mereka yang tidak puas dapat melakukan dengan cara melampiaskan dendam dengan cara menjatuhkan musuh atau lawan atau saingan atau kompetitor mereka dengan cara melakukan ancaman, penghinaan atau perbuatan tidak menyenangkan. Yang perlu diketahui adalah cyber crime itu sendiri merupakan suatu bentuk kejahatan yang baru ataukah suatu bentuk kejahatan konvensional yang mana hanya menggunakan teknologi sebagai sarana dan prasarana serta sasarannya, sebab karakteristik dari cyber crime hampir mirip dengan kejahatan konvensional, dimana penggunaan teknologi computer dan internet atau media telekomunikasi berupa handphone pada saat melakukan kejahatan pencemaran nama baik atau penipuan seperti pada kejahatan pada umumnya atau konvensional dimana modusnya adalah menggunakan selebaran kertas yang di tempelkan di muka umum atau melakukan penipuan secara verbal anta individu yang satu dengan yang satu.

Perbedaan yang cukup mendasar dalam proses atau prosedur pada sistem tindak pidana konvensional dengan tindak pidana elektronik tersebut berpengaruh dengan adanya bentuk dan sifat yang berbeda dalam hal ini tindak 
pidana elektronik adalah tindak pidana telematika. Perbedaan tersebut menurut Al. Wisnubroto adalah (Joni Emirzon, dkk, 2007: 376) :

Tabel 1. Perbedaan antara Kejahatan Konvensional dan Kejahatan Telematika

\begin{tabular}{|c|l|l|}
\hline & \multicolumn{1}{|c|}{ Kejahatan Konvensional } & \multicolumn{1}{c|}{ Kejahatan Telematika } \\
\hline $\begin{array}{c}\text { Alat/ } \\
\text { sarana }\end{array}$ & $\begin{array}{l}\text { Tradisionil (kunci palsu, Surat/ } \\
\text { Dokumen palsu, senjata api/ } \\
\text { Tajam, kendaraan, dll. }\end{array}$ & $\begin{array}{l}\text { Teknologi ( komputer, Telepon/ HP, } \\
\text { Internet, Magnetic card dll ) }\end{array}$ \\
\hline Sasaran & $\begin{array}{l}\text { Barang atau jasa serta aset riel yang } \\
\text { bernilai ekonomis }\end{array}$ & $\begin{array}{l}\text { Barang, Jasa, Informasi, data, program, } \\
\text { HaKI yang berniali ekonomis }\end{array}$ \\
\hline Pelaku & $\begin{array}{l}\text { Bisa siapa saja karena unsur “otot" } \\
\text { masih menonjol di bandingkan } \\
\text { "otak" }\end{array}$ & $\begin{array}{l}\text { Perlu kemampuan intelektual tinggi dan } \\
\text { proffesional karena unsur "otak" sangat } \\
\text { dominan }\end{array}$ \\
\hline $\begin{array}{c}\text { Ruang } \\
\text { Lingkup }\end{array}$ & $\begin{array}{l}\text { Masih nampak batas teritorialitas- } \\
\text { nya (mudah menentukan batas } \\
\text { yurisdiksinya ) }\end{array}$ & $\begin{array}{l}\text { Transnasional dan borderless ( antara } \\
\text { pelaku, korban dan TKP bisa berbeda di } \\
\text { wilayah negara yang berbeda ) }\end{array}$ \\
\hline $\begin{array}{c}\text { Modus } \\
\text { operandi }\end{array}$ & $\begin{array}{l}\text { Relatif sederhana, mudah ter- } \\
\text { identifikasi }\end{array}$ & $\begin{array}{l}\text { Lebih kompleks, variasinya berkembang } \\
\text { cepat ( adaptasi teknologi dan sistem ) }\end{array}$ \\
\hline
\end{tabular}

Dari uraian tersebut dapat dilihat antara perbedaan tindak pidana cyber crime atau kejahatan telematika, dengan tindak pidana konvensional dimana memang berbeda dengan kejahatan siber, dalam arti memiliki unsur yang berbeda, jadi kejahatan telematika bukanlah tindak pidana konvensional yang hanya dengan modus baru. Sebab bila melihat dari perbedaan terlihat perbedaan yang mencolok baik dari segi pelaku, modus, sasaran dan sifatnya, walaupun ujungnya berupa kejahatan.

\section{B. Pembobolan Rekening Bank dan e-money sebagai Bentuk Kejahatan Cyber Crime}

Kejahatan yang dilakukan oleh para pelaku dengan memanfaatkan teknologi lazimnya biasa di sebut sebagai hacker ( Al wisnubroto, 2001: 114). Hacker atau istilah yang sebenernya yang lebih di takuti dalam dunia internet adalah cracker (Al wisnubroto, 2001: 114). Dalam literatur hacking diartikan sebagai: penyambungan dengan cara menambah terminal komputer baru pada sistem jaringan komputer secara melawan hukum (ilegal) atau tanpa ijin dari pemilik sah jaringan komputer tersebut (Andi Hamzah, 1987: 36). Walaupun pada prakteknya terdapat hacker ada yang bersifat baik dan bersifat buruk (Abdul Wahib dan Muhammad Labib, 2005: 89). Sifat buruknya sudah jelas yakni dengan meretas atau merusak sistem pada jaringan jaringan internet 
secara ilegal, demikian dengan sifat baik yang bertolak belakang dengan sifat buruk yakni dengan memeperbaiki sistem yang telah di rusak oleh para peretas.

Sifat baik yang di lakukan oleh hacker sebenarnya bertujuan baik akan tetapi juga menyalahi aturan karena dalam memperbaiki juga harus masuk kedalam sistem, akan tetapi sistem yang di masukin juga secara ilegal. Bila ditafsirkan kedalam dunia nyata dan ditafsirkan sebagai kejahatan yang konvensional maka dapat di artikan sebagai memasuki wilayah tanpa izin seperti yang di atur di dalam pasal 167 KUHP.

Hacker dalam melakukan aksinya ada beberapa tahapan yang di lalui yaitu, sebabaigai berikut (Edmon Makarim, 2003: 402):

1. Mencari sistem komputer yang hendak dimasuki;

2. Menyusup dan menyadap password;

3. Menjelajahi sistem komputer;

4. Membuat backdoor dan menghilangkan jejak.

Para pelaku hacking yang melakukan tindakan pembobolan bank biasanya adalah carding (carder) dengan melakukan transaksi atau berbelanja dengan sejumlah barang dengan nomor kartu kredit orang lain pada fasilitas $e$ commerce dengan terlebih dahulu menyusup dan menyadap nomor kartu kredit beserta kode sandi tersebut. Perbuatan tersebut dengan memanipulasi demi mengambil uang atau barang melalui akses e-commerce.

Permasalahan yang ada dalam kasus seperti itu adalah laporan yang masuk terjadi setelah pembayaran barang ternyata di tolak oleh bank dan barang sudah di terima oleh pelaku, sehingga disini terdapat pihak penjual yang di rugikan atas dasar penipuan. apabila hal ini bukan dilakukan didunia maya maka kejahatan ini merupakan kejahatan konvensional sebagai bentuk kasus penipuan yang tercantum dalam pasal 378 KUHP. Selain dari pada itu kejahatan cyber crime dalam e-commerce adapula yang dalam dunia nyata dikatakan sebagai bentuk penipuan adalah adanya penjualan barang secara online baik melalui situs internet atau melalui media informasi elektronik melalui gadged smartphone sebagai online shop di mana biasanya penjual tidak memiliki barang yang sebenarnya telah ditawarkan kepada pembeli. Sangat disarankan apabila 
dalam bertransaksi jual beli secara online ada baiknya dilakukan secara langsung dan tunai dan berhadapan serta bertatap muka langsung antara penjual dan pembeli. Tujuan tersebut di lakukan untuk menghindari segala bentuk kemungkinan yang terburuk dapat terjadi.

Transaksi yang dilakukan dengan sistem atau cara bertemu secara langsung antara penjual dan pembeli benar adanya, selain untuk keamanan dan kenyamanan bersama adalah apabila telah terjadi tindak pidana cyber crime tersebut maka sekiranya akan sulit dalam dilakukan penangkapan. Bila kejahatan mayantara tersebut di lakukan melalui intenet maka, hasil pelacakan paling jauh hanya dapat menemukan IP address dari pelaku dan komputer yang digunakan. Hal itu akan semakin sulit apabila menggunakan warnet sebab saat ini masih jarang sekali warnet yang melakukan registrasi terhadap pengguna jasa mereka sehingga kepolisian tidak dapat mengetahui siapa yang menggunakan komputer tersebut pada saat terjadi tindak pidana. (Besse Sugiswati, 2011: 64) Disini bukan berarti Indonesia menolak akan perkembangan zaman, akan tetapi sebagai bentuk preventif untuk mencegah halhal yang tidak diinginkan terhadap penipuan maupaun pembobolan rekening pada e-money, dengan demikian jual beli online dengan media kompter dan jaringan internet, hanya sebgai sarana dalam jual beli. Sebab apabila kejahatan tersebut dilakukan melalui Gadged smartphone mauapun situs serta aplikasi jual beli online seperti tokopedia atau bukalapak bahwa akan kesulitan dalam melakukan penangkapan sebab korban tidak akan mengetahui ciri ciri serta wajah dari pelaku. Salah satu bentuk kejahatan pembobolan nomor rekening dalam transaksi electronic adalah Infringements of privacy (Abdul Wahid dan Muhammad Labib, 2003: 72). Kejahatan ini di tujukan terhadap informasi seseorang yang merupakan hal yang sangat pribadi dan rahasia, dilakukan untuk memperoleh keuntungan bagi para pelaku, kejahatan ini biasanya adalah dengan melakukan pembobolan nomor ATM dan nomor PIN biasanya kejahatan ini tidak hanya di lakukan dalam transaksi e-commerce saja, akan tetapi bisa dilakukan juga dalam keadaan apapun selama pelaku kejahatan ini telah mengetahui nomor ATM atau rekening, dan lebih mudah dilakukan apabila 
terdapat orang dalam pihak bank. tetapi walau bagaimanapun juga kjehatan ini sangat merugikan korban secara materil maupun immateriil.

\section{Tindak Pidana Cyber Crime yang Masuk Kedalam Kategori Tindak Pidana Ekonomi}

Dalam sebuah terjadinya tindak pidana atau suatu terjadinya delik, yang dalam bahasa latin "delictum" adalah perbuatan yang dilarang dan di ancam dengan pidana kepada barang siapa yang melanggar larangan tersebut). (Moeljanto, 1977: 2) Sebagaimana tujuan dari hukum pidana itu sendiri adalah untuk mencegah penghambatan atau penghalangan masyarakat yang di cita citakan oleh bangsa indonesia yaitu dengan jalan penentuan perbuatan perbuatan manakah yang pantang dan tidak boleh di lakukan, serta pidana apakah yang diancam kepada mereka yang melanggar larangan larangan itu (Moeljanto, 1977: 2-3). Dengan kata lain adalah segala sesuatu yang merugikan masyarakat. Begitu pula bahwa masyarakat disini adalah masyarakat dalam kehidupan nyata, tetapi didalam kenyataanya dengan kemajuan sebuah Ilmu Pengetahuan sehingga tercipta suatu teknologi, maka secara tidak langsung adalah timbulnya atau lahirlah sebuah peradaban baru atau bentuk sosial baru yakni masyarakat maya, yang merupakan cermianan dari masyarakat nyata.

Dari hal tersebut dapat dilihat bahwa dengan adanya masyarakat maya maka secara tidak langsung pun akan timbul suatu bentuk tindak pidana, hal perlu kita ingat adalah bahwa masyarakat maya merupakan masyarakat nyata hanya atas perubahan "locus"-nya yang berbeda, seperti yang sebelumnya di kemukakan oleh pembukaan undang undang dasar bahwa negara melindungi segenap bangsa dan memajukan kesejahteraan umum, maka atas keterkaitan tersebut. Pemerintah harus melindungi warga negara dari segala tindak pidana serta pemerintah harus memberikan kebebasan masyarakat dengan memaksimalkan kebijakan demi pertumbuhan perekonomian warga negara.

Tindak pidana di dalam teknologi tinggi yang berbasis jaringan atau bisa dikatakan sebagai cyber crime atau kejahatan siber. Yang perlu di cermati adalah bahwa tindak pidana cyber crime tidak syarat dengan memenuhi unsur ekonomi yang artinya adalah tidak selalu cyber crime dapat di kategorikan 
sebagai tindak pidana ekonomi, akan tetapi dapat di katakan sebagai bentuk tindak pidana khusus yang artinya memang sifat pengaturannya di luar KUHP dan penangananya di lakukan secara khusus dan berbeda dengan tindak pidana konvensional pada umumnya.

Seperti yang di ungkapkan oleh penulis sebelumnya, bahwa media elektronik di rasa sangat penting bagi mereka masyarakat yang bergerak di bidang bisnis, sebab kemajuan ekonomi suatu bangsa salah satunya dipengaruhi oleh promosi barang-barang produksi. Produk barang yang dihasilkan oleh industri di Indonesia sangat banyak dan digemari oleh komunitas Internasional. Para pelaku bisnis harus mampu memanfaatkan sarana internet dimaksud. Krisis ekonomi yang melanda bangsa Indonesia harus dijadikan pelajaran bagi masyarakat Indonesia untuk bangkit dari krisis dimaksud. Seluruh komponen bangsa Indonesia harus berpartisipasi mendukung pemulihan ekonomi. Media internet dan jaringan komputer merupakan salah satu media yang dapat dimanfaatkan oleh seluruh masyarakat untuk mempromosikan Indonesia.

Akan tetapi bentuk kejahatan cyber crime memiliki banyak dan jenis serta beragam bentuknya, oleh karena itu agar dapat mengetahui tindak pidana yang seperti apakah yang dapat di kategorikan sebagai tindak pidana cyber crime dalam konteks pidana ekonomi. Ari Juliano Gema menyatakan bahwa dala literatur dan praktik kejahatan yang berhubungan dengan penggunaan teknologi yang berbasis utama komputer dan jaringan telekomunikasi (cyber crime) dikelompokan dalam beberapa bentuk, diantaranya yaitu (Abdul Wahid dan Muhammad Labib, 2003: 72) Unauthorized Access dan Infringements of privacy.

Selain bentuk kejahatan tersebut kejahatan cyber crime muncul dalam berbagai bentuk varian, Bentuk tersebut berdasarkann data menurut NCIS di inggris diantaranya (Abdul Wahid dan Muhammad Labib, 2003: 70-72) Cracker atau criminalminded hacker, dan Internal hacker.

\section{Konsep Pandangan Hukum Pidana Pembobolan Rekening Bank dan e-money Melalui Media Elektronik dalam Dunia Maya}




\section{Pandangan umum mengenai $e$-money}

Saat ini sudah banyak sekali situs internet yang berbasis applikasi pada platform android maupun ios yang menawarkan perbelanjaan secara online, seperti diantaranya tokopedia, bukalapak, lazada, shopee bahkan aplikasi jasa angkutan yang dapat dipanggil melalui jaringan berbasis aplikasi, seperti gojek ataupun grab. Melalui aplikasi yang sebelumnya telah disebutkan dalam hal pembayarannya menggunakan sistem uang elektronik atau e-money atau uang yang dibayarkan tidak dalam bentuk fisik yang secara konkrit. Pada dasarnya pembayaran dengan sistem elektronik tersebut memiliki banyak manfaatnya.

Perbedaan utama antara e-money dengan kartu debit maupun kartu kredit yakni terkait pada informasi data pemegang yang artinya $e$ money tidak menggunakan data diri sebagaimana pada kartu debit maupun kartu kredit. Disamping itu pula pada e-money tidak adanya biaya tambahan atau potongan bagi sipemegang atau pemilik dari e-money tidak seperti kartu debit maupun kartu kredit yang setiap penggunaanya selalu dibebenkan berupa potongan bagi pemilik atau pemegang kartu kredit tersebut.

Pengertian e-money itu sendiri didefinisikan sebagai alat pembayaran dalam bentuk elektronik dimana nilai uangnya disimpan dalam media elektronik tertentu. (Bank Indonesia, Edukasi Perlindungan Konsumen, diakses pada 22 Desember 2019) Penggunanya harus menyetorkan uangnya terlebih dahulu kepada penerbit dan disimpan dalam media elektronik sebelum menggunakannya untuk keperluan bertransaksi. Ketika digunakan, nilai uang elektronik yang tersimpan dalam media elektronik akan berkurang sebesar nilai transaksi dan setelahnya dapat mengisi kembali (top-up). Media elektronik untuk menyimpan nilai uang elektronik dapat berupa chip atau server. Penggunaan uang elektronik ini sebagai alat pembayaran yang inovatif dan praktis diharapkan dapat membantu kelancaran pembayaran kegiatan ekonomi yang bersifat massal, cepat dan mikro. (Bank Indonesia, Edukasi Perlindungan Konsumen, diakses pada 22 Desember 2019) 
Pengaturan e-money itu sendiri telah dituangkan didalam Peraturan Bank Indonesia Nomor: 11/12/PBI/2009 tentang Uang Elektronik (Electronic Money) yang kini sudah diperbarui menjadi PBI Nomor: 18/ 17/PBI/2016 dan Surat Edaran Bank Indonesia No.11/11/DASP tanggal 13 April 2009 perihal Uang Elektronik (Electronic Money), e-money diterbitkan atas dasar nilai uang yang disetor terlebih dahulu oleh pemegang kepada penerbit dan nilai uang tersebut disimpan secara elektronik dalam suatu media seperti server atau chip. Artinya $e$ money yang beredar didunia maya bukan semata - mata hanya uang yang abstrak dan tidak pernah berwujud, akan tetapi merupakan uang yang sejak awal merupakan uang fisik yang berlaku kemudian dirubah menjadi uang elektronik. Uang elektronik itu sendiri sebenarnya juga menggunakan mata uang yang sama diIndonesia yakni Rupiah, akan tetapi beberapa penyelenggara uang elektronik merubah dalam bentuk "point" Seperti yang ada didalam tokopedia yang bekerjasama dengan OVO, akan tetapi tidak semata-mata "point" tersebut menjadi mata uang melainkan "point" tersebut ditukar kedalam bentuk rupiah sesuai dengan pihak penyelenggara.

Walapun di satu sisi terdapat beberapa manfaat dari Uang Elektronik, tetapi di sisi lain terdapat risiko yang perlu disikapi dengan kehati-hatian dari para penggunanya, seperti: (Bank Indonesia, Edukasi Perlindungan Konsumen, diakses pada 22 Desember 2019)

a. Risiko uang elektronik hilang dan dapat digunakan oleh pihak lain, karena pada prinsipnya uang elektronik sama seperti uang tunai yang apabila hilang tidak dapat diklaim kepada penerbit.

b. Risiko karena masih kurang pahamnya pengguna dalam menggunakan uang elektronik, seperti pengguna tidak menyadari uang elektronik yang digunakan ditempelkan 2 (dua) kali pada reader untuk suatu transaksi yang sama sehingga nilai uang elektronik berkurang lebih besar dari nilai transaksi.

Melihat dari resiko diatas, menggambarkan bahwa Uang eleketronik atau e-money tidak luput dari kejahatan dunia maya yang dapat merugikan 
pemilik uang elektronik dalam hal ini user (pengguna) maupun penyelenggara dari uang elektronik itu sendiri atau $e$-money.

\section{Pemikiran hukum pidana pada kejahatan pembobolan rekening bank} dan $e$-money dalam e-commerce sebagai tindak pidana ekonomi

Dalam hukum pidana dikenal dengan asas legalitas sebagai mana yang telah diutarakan pada sebelumnya, bahwa suatu perbuatan dianggap bukan sebagai kejahatan apabila belum diatur dalam undang - undang. Dengan berjalannya perkembangan, maka banyak perbuatan baru yang timbul, dan perbuatan baru yang timbul juga diiringi dengan kejahatan dalam hal yang baru tesebut. Terdapat Adigium yang berbunyi Het Recht Hink Achter De Feiter Aan yang mengatakan bahwa hukum selalu tertinggal satu langkah dibanding kejahatan. Dengan demikian bahwa berjalannya suatu perkembangan dengan adanya e-money maka juga akan timbul kejahatan. Dengan demikian dapat dikatakan kejahatan pembobolan rekening bank maupun e-money merupakan manifestasi dari bentuk perkembangan dari kejahatan itu sendiri.

Kejahatan yang terjadi pada pembobolan rekening bank maupun $e$ money dapat dikatakan sebagai bentuk kejahatan apabila dipandang sebagai kejahatan oleh masyarakat dan ada ketentuan yang telah mengatur sebelumnya. Pada dasarnya hukum yang ada dan terbentuk itu sendiri timbul dari bersama masyarakat sebagaimana yang diungkapkan oleh von savigny Das Recht wird nicht gemacht, est ist und wird mit dem Volke" (Hukum itu tidak dibuat, tetapi tumbuh dan berkembang bersama masyarakat). (Lili Rasjidi dan Ira Thania Rasjidi, 2002: 63) Jadi hukum yang mengatur dan menyatakan bahwa pembobolan rekening bank maupun e-money yang terjadi pada dunia maya pada transaksi e-commerce sebagai perbuatan pidana juga terbentuk dan tumbuh dari perkembangan masyarakat, yang kemudian dikonkritkan kedalam bentuk tertulis berupa peraturan perundang-undangan bahwa dalam hukum pidana harus tertulis (scripta), Ketat (stricta), dan Tegas (certa). Akan tetapi, sebelum perbuatan tersebut dikatakan sebagai perbuatan pidana akan tetapi e-money dan 
penggunaanya pada e-commerce terlebih dahulu sudah harus diakui dan diatur dalam hukum.

Berdasarkan contoh kasus singkat di atas tersebut pada bab sebelumnya dan bentuk bentuk kejahatan yang telah di uraikan oleh penulis, maka penulis akan mencoba menganalisis mengenai kejahatan pembobolan rekening bank yang terjadi didalam transaksi ekonomi (e-commerce), dimana banyak sekali peluang terjadinya kejahatan didunia maya atau kejahatan mayantara yang terjadi berupa pembobolan rekening bank bagi para nasabah yang akan melakukan transaksi keuangan.

Pembobolan rekening yang di lakukan oleh pelaku dalam melakukan Hacking atau meretas sebuah sistem dilakukan dengan tujuan atau dengan motif Ekonomi yakni dengan berbagai cara mulai cara termudah adalah dengan melakukan penipuan secara elektronik menggunakan telepon genggam atau melalui pesan singkat dengan modus transaksi on-line hingga kejahatan yang sulit dilakukan dengan cara melakukan peretasan terhadap sistem keamanan guna mendapatkan nomor kode rahasia pada rekening bank yang semata mata demi keuntungan materi. Kejahtan dari hal yang paling mudah juga merupakan kejahatan yang terjadi tidak secara langsung dengan artian antara pelaku dengan korban tidak bertatap muka dengan hanya bermodalkan atas kepercayaan, oleh karena itu akan sangat rentan terhadap tindak pidana. Perbuatan tersebut dapat di kategorikan sebagai kejahatan siber dibidang ekonomi selama perbuatan tersebut mengandung suatu unsur atau berbau motif ekonomi.

Perbuatan pidana yang dilakukan dengan media elektronik baik menggunakan jaringan atau tidak menggunakan jaringan internet selama kejahatan tersebut merugikan seseorang dibidang finansial maka kejahatan tersebut merupakan kejahatan dengan tujuan ekonomi. Sehingga dapat melihat keterkaitannya antara cyber crime dengan kejahatan tindak pidana ekonomi bahwasahnya perbuatan tersebut mangenai delik di dalam delik pidana cyber crime terkandung unsur ekonomi, adapun bila di dalam unsur delik tersebut tidak adanya muatan ekonomi akan tetapi dapat dilihat efek 
atau akibat yang ditimbulkan atas perbuatan kejahatan siber tersebut. Perbuatan tindak pidana kejahatan telematika yang memang murni sebagai bentuk tindak pidana tanpa adanya unsur ekonomi seperti tertuang di dalam Undang undang No. 11 Tahun 2008 jo Undang-Undang No.19 Tahun 2016 tentang perubahan Undang-Undang Nomor 11 Tahun 2008 yakni diantaranya Pasal 28 ayat 2, Pasal 29.

Diluar pasal tersebut merupakan tindak pidana cyber crime yang memiliki muatan mengenai ekonomi, menurut hemat penulis kejahatan pada dunia siber sekalipun itu cyber terrorism, selama kejahtaan tersebut merugikan seseorang yang berkenaan dengan finansial merupakan kejahatan yang dilakukan pada bidang ekonomi.

Kejahatan mayantara yang sering terjadi dan menimbulkan permasalahan hukum di klasifikasikan oleh sarjana Eropa bernama Schjo/Iberg dari Denmark (1986) membagi menjadi 6 (enam) bagian (Moh. Hatta, 2010: 219): Pencurian, penggelapan, penipuan, pemalsuan, tanpa hak memasuki data program (DP) sistem, serta tanpa hak menggunakan komputer dan pencurian waktu atau fasilitas komputer.

Dari ungkapan Sarjana tersebut dapat di katakan juga bahwa tindak pidana cyber crime mirip dengan kejahatan biasa hanya saja dengan tambahan teknologi, seandainya perbuatan delik tersebut tanpa teknologi maka dapat dikatakan sebagai delik biasa seperti Penipuan dan penggelapan, bila tidak dilakukan dengan teknologi maka tindak kejahatan tersebut masuk kedalam kategori kejahatan yang tercantum dalam pasal 372 dan 378 KUHP dan dapat dikatakan sebagai kategori kejahatan biasa walaupun ada unsur materi didalamnya, lantas kenapa kejahatan $e$ commerce masuk kedalam tindak pidana ekonomi. Menurut hemat penulis berdasarkan bahwa perbuatan tersebut diakakukan dengan menggunakan teknologi dan juga mengandung unsur ekonomi yakni dalam transaksi elektronik.

Oleh karena itu dalam hal tindak pidana cyber crime memiliki karakteristik yang berbeda, antara tindak pidana cyber crime sebagai tindak 
pidana kriminal murni dalam kategori khusus dengan cyber crime sebagai tindak pidana yang berkaitan dengan ekonomi khusus. Dalam hal tindak pidana membobol rekening dengan cara menyusup kedalam sistem sebenarnya bisa di terjemahkan kedalam kejahatan konvensional yakni memasuki pekarangan orang tanpa izin, artinya kejahatan yang dilakukan didalam dunia maya hampir mirip dengan kejahatan konvensional. Dimana adanya perluasan makna atau penafsiran yang diperluas dalam mengartikan kejahatan un-konvensional kedalam kejahatan konvensional.

\section{Penutup}

\section{A. Kesimpulan}

Cyber crime merupakan tindak pidana yang dihasilkan oleh komuniatas sosial baru yakni cerminan dari masyarakat nyata menjadi masyarakat maya. Kejahatan yang di lakukan oleh masyarakat tersbut dalam tindak pidana ekonomi salah satunya yg diangkat oleh penulis adalah mengenai pembobolan bank dalam hal ini rekening bank baik yang terjadi didalam e-commerce, dimana e-commerce itu sendiri merupakan transaksi yang dilakukan melalui teknologi tinggi antara indvidu yang satu dengan individu yang lain yang tidak ada batasnya atau jaraknya berjauhan. akan tetapi didalam transaksi tersebut ternyata sudah di Intai atau diinti oleh segelintir masyarakat maya untuk melakukan tindakan pidana yang semata mata dapat merugikan banyak orang, dimana mereka para peretas akan melakukan pembobolan dengan berbagai cara. diantaranya adalah mereka para carding melakuakn transaksi dengan membobol nomor rekening atau kartu kredit serta nomor PIN seperti Infringements of privacy, yang merupakan salah bentuk kejahatan dunia maya dalam transaksi $e$ commerce walaupun tidak hanya itu seperti penipuan antara penjual dan pembeli dalam on-line shop atau e-commerce, dimana penjual sudah mentransfer sejumlah uang tetapi barang yang seharusnya dikirim tidak kunjung dikirim dan mauapun perbuatan yang merugikan secara finansial yang terjadi didunia maya, maka perbuatan tersebut juga merupakan kejahatan dibidang ekonomi yang menggunakan fasilitas elektronik yang pada prinsipnya kejahatan yang 
menggunakan teknologi canggih yang berkaitan dengan dunia maya baik internet ataupun telepon selular dimana dunia tersebut tidak secara fisik atau abstrak dengan tujuan atau motif untuk memperkaya diri sendiri dapat di kategorikan sebagai tindak pidana dengan motif ekonomi dan dengan adanya kejahatan tersebut dapat dikatakan sebagai kejahatan ekonomi dikarenakan akan memepengaruhi kestabilitasan perekonomian bangsa dengan hilangnya kepercayaan masyarakat untuk menyimpan keuangannya di bank dan enggannya masyarakat untuk melakukan transaksi e-commerce, sedangkan fenomena $e$ commerce sudah tidak mungkin untuk dihindari lagi sebagai bentuk kemajuan jaman.

\section{B. Saran}

Pemerintah harus lebih serius dalam menangani dengan baik masalah cyber crime dan perlunya pemerintah membuat sebuah lembaga baru yang SDM-nya adalah ahli dibidangnya berupa informatika dengan disertai kebijakan yang lebih di sempurnakan yang isinya lebih mendetail mengenai kejahatan cyber crime dan beserta penanggulangannya baik dalam sarana Penal maupun non-penal, sebab masyarakat indonesia memerlukan sebuah perlindungan terhadap keuangan atau materi tidak hanya itu saja masyarakat juga memerlukan perlindungan terhadap transaksi elektronik yang lebih baik tentunya pihak pemerintah maupun pihak swasta yang memang berkaitan dengan penyedia jasa atau jaringan dunia maya yang bertujuan agar tidak terjadinya ancaman yang merugikan yang dilakukan oleh para pelaku di dalam dunia maya.

\section{Daftar Pustaka}

Al. Wisnubroto. Kebijakan Hukum Pidana dalam Penanggulangan Kejahatan Komputer. Yogyakarta: Universitas Atmajaya, 2001. , Strategi dalam Penanggulangan Kejahatan Telematika.

Yogyakarta: Atma Jaya, 2010.

Emirzon, Joni, dkk. Perspektif Hukum Bisnis Indonesia pada Era Globalisasi Ekonomi. Yogyakarta: Genta press, 2007. 
Hatta, Moh. Kebijakan Politik Kriminal. Yogyakarta : Pustaka Pelajar, 2010.

Rasjidi Lili, Ira Thania Rasjidi. Pengantar Filasafat Hukum. Bandung: Mandar Maju, 2002.

Soekanto, Soerjono. Pengantar Penelitian Hukum. Jakarta: Universitas Indonesia Press, 1986.

Sudarto. Hukum Pidana dan Perkembangan Masyarakat. Bandung: Sinar Baru, 1983.

Sugiswati, Besse. Majalah Perspektif, Volume XVI No.1, Surabaya, 2011.

Wahid, Abdul dan Muhammad Labib. Kejahatan Mayantara (Cyber Crime). Bandung : Refika Aditama, 2005.

Republik Indonesia. Undang-Undang Dasar Negara Republik Indonesia 1945. , Undang-Undang Darurat Nomor 7 Tahun 1955 tentang pengusutan, penuntutan dan peradilan tindak pidana ekonomi. Lembaran Negara Tahun 1955 No.27. Tambahan Lembaran Negara Nomor 801. , Undang-Undang Nomor 19 tahun 2016 Tentang perubahan atas Undang-undang No.11 Tahun 2008 Tentang informasi dan transaksi elektronik. Lembaran Negara Tahun 2016 No. 251. Tambahan Lembaran Negara Nomor 5952. , Kitab Undang Undang Hukum Pidana , Peraturan Bank Indonesia Nomor: 18/17/PBI/2016 Tentang Uang Elektronik

Bank Indonesia, Surat Edaran Bank Indonesia No.11/11/DASP tanggal 13 April 2009 perihal Uang Elektronik (Electronic Money).

Bank Indonesia. "Edukasi dan Perlindungan Konsumen SP”. (https://www.bi.go .id/id/edukasi-perlindungan-konsumen/edukasi/produk-dan-jasa-sp/uangelektronik/Pages/default.aspx), diakses pada 22 Desember 2020. 